\title{
Size differences in the Dufour gland of Apis mellifera Linnaeus (Hymenoptera, Apidae) between and within the female castes
}

\author{
Fábio Camargo Abdalla ${ }^{1}$ \\ Carminda da Cruz-Landim ${ }^{1}$
}

\begin{abstract}
The Dufour gland is found closely associated with the sting apparatus of all hymenopteran females, playing multiple roles among bees. In Apis mellifera Linnaeus, 1758 the gland is connected to the dorsal vaginal wall and, in queens, it produces egg-marking pheromones. In workers the function of this gland is unknown, except by its capacity to mimic the queen secretion in egg-laying workers. In an attempt to understand the development and to substantiate the present knowledge about the Dufour gland in A. mellifera, a morphometric study of the gland between and within the female castes was made. Glands of workers and queens with different ages and life stages were dissected and measured with an ocular micrometer adapted to a stereoscope. The results showed that the Dufour gland is larger in queens than in workers, and that among workers, the gland is larger in egg-laying and foragers than it is in newly emerged and nurse workers. The larger size of the gland in egg-laying queens and workers is in accordance with its role in reproduction. In forager workers the larger size of the gland suggest that, as happens in some species of bees, the gland may participate in pheromone production for nest-mate or nest-entrance recognition.

KEY WORDS. Apis mellifera, Dufour gland, exocrine glands
\end{abstract}

All insects have accessory glands associated to the female reproductive apparatus; these glands are also known as colleterial glands. The original function of these glands is to facilitate the oviposition and to protect the eggs.

The Dufour gland of the aculeated hymenopterans is considered homologous of the colleterial glands of the other insects, being found associated to the sting apparatus of all hymenopteran females, even in those with atrophied sting (KERR \& LELlo 1962; BILLEN 1986; HeFETZ 1987).

In hymenopterans the Dufour gland is often described as a single tube or epithelial sac, partially involved by muscular fibbers, tracheoles and nerves. The glandular epithelium is constituted by a single layer of epithelial cells, whose luminal surface is covered by a thick and undifferentiated cuticle (BILLEN 1986; ABDALla \& CRUZ-LANDiM 1996, 1997; ABDalla et al. 1999a,b).

The morphology of the Dufour gland varies along the hymenopteran lineage, between the castes in a same species and among the individuals of the same caste with different ages, or doing different tasks in the colony of the social species (KERR \& Lello 1962; LELLO 197 la,b,c,d; Billen 1986; ABDALla et al. 1999a,b).

1) Departamento de Biologia, Instituto de Biociências de Rio Claro, Universidade Estadual Paulista. Avenida 24A, 1515, 13506-900 Rio Claro, São Paulo, Brasil.

E-mail: fabdalla@rc.unesp.br

Revta bras. Zool. 18 (Supl. 1): 119 - 123. 2001 
Among the bees, the Dufour gland is larger in bees situated bellow in the phylogenetic tree. In Colletidae, Halictidae and Andrenidae the gland is large, in Megachilidae there is a decreasing of its diameter, in Mellitidae there is a decreasing of its length and in Anthophoridae there is a decreasing in both dimensions, being the gland in Apidae small and even vestigial or absent in Meliponinae that have atrophied sting (LELLO 1971 a,b,c,d).

In Apis mellifera Linnaeus, 1758 the Dufour gland secretion is used to mark the eggs laid by the queen, preventing them from being devoured by the inspecting workers. In workers the gland function is unknown, except its capacity to mimic the queen secretion in egg-layer workers under orphanage condition (KATZAV-GoZANSKY et al. 1997).

Size variation of the Dufour gland with different ages and life stages of the female castes in A. mellifera was investigated. An attempt is made of correlate the size variation to the gland function as known by the corresponding literature reports.

\section{MATERIAL AND METHODS}

The Dufour glands of newly-emerged, nurse, forager and egg-layer workers, as well as of newly emerged and egg-laying queens (12 till 18 months old), from colonies maintained at the Department of Biology (Universidade Estadual Paulista - Unesp - Rio Claro, Brazil), were dissected in physiologic solution and their length and diameter measured with an ocular micrometer adapted to a stereoscope.

The egg-laying workers were collected from a queenless colony, where worker oviposition was beforehand observed.

Data were submitted to the Tukey-test with $5 \%$ level of significance to verify differences among the measurements of the groups studied.

\section{RESULTS AND DISCUSSION}

The Dufour gland of Apis mellifera workers has a very special morphology, its wall is folded like wind-chest of an accordion, being able to increase its size (length and width) according to the amount of secretion stored into the glandular lumen (ABDALLA \& CRUZ-LANDIM 1996, 1997). The monolayered epithelium presents many infoldings and when the glandular lumen is empty they are very close one to the other (Fig. 1A,B). On the other hand, if the lumen is filled with secretion the epithelial infoldings that withdraw and the lumen opens, permitting the gland decreases in diameter and increases in length (Fig. 1C,D).

The variance analysis indicated differences among the groups analysed. The Dufour gland show size variation according to the age and to the tasks performed by the female castes, being larger in queens than in workers, and that among workers, the gland is larger in egg-laying and forager workers than it is in newly emerged and nurse workers. Newly-emerged queens have shorter glands than egg-laying ones, maintaining the same width (diameter) in both queen types studied (Tab. I).

In newly-emerged and nurse workers the gland is short because its empty lumen is collapsed and the epithelium infoldings are close one to the other, so that the gland presents a small length, but a large diameter. In forager workers the gland 
A

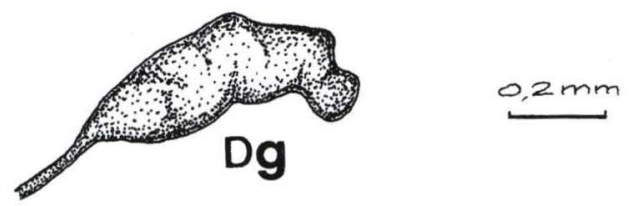

B

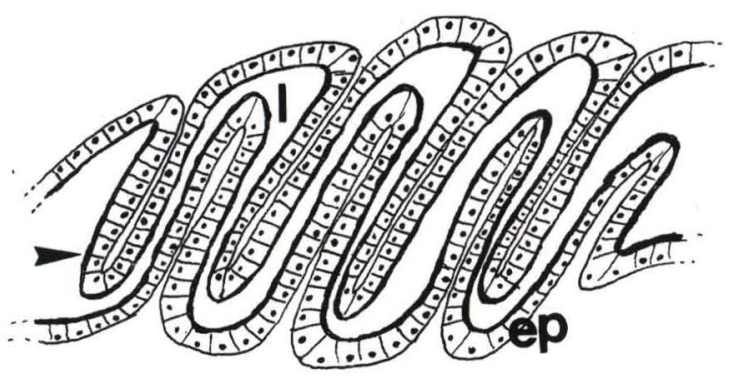

$0,05 \mathrm{~mm}$

C

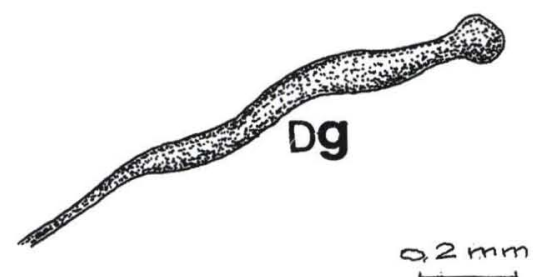

D

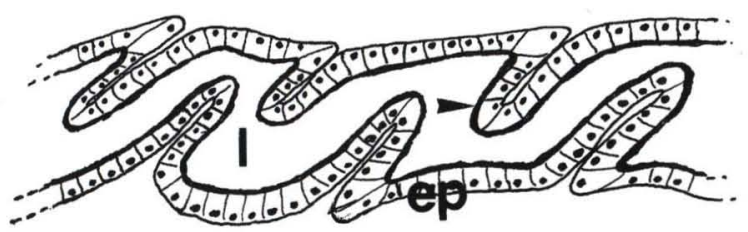

$0.1 \mathrm{~mm}$

Fig. 1. Scheme of Dufour gland epithelium (Ep) variation of Apis mellifera workers. In newlyemerged workers (A) the Dufour gland (Dg) has a empty lumen (I) with many epithelium infoldings $(B$, arrow). On the contrary, in egg-layers and foragers $(C)$ the lumen $(I)$ is open and filled with secretion (D). The opened lumen $(I)$ withdraws the epithelial infoldings (arrow), permitting the gland decreases in diameter (width) and increases in length. 
is more extended with more secretion into the glandular lumen, which causes increasing of its length and decreasing of its diameter.

In egg-laying workers the gland has the same length showed by the foragers, but its lumen contains more secretion. Therefore, its diameter is also lager. On the contrary, the gland diameter between the analysed queens does not vary, but the length in egg-laying is larger than in newly-emerged.

Table I. Measurements of the length and diameter of the Dufour gland of Apis mellifera and statistical analysis of the data. (CV) Coefficient of variation, $(\mathrm{N})$ number of individuals analysed.

\begin{tabular}{|c|c|c|c|c|c|c|}
\hline \multirow{2}{*}{ Caste } & \multirow{2}{*}{ Individuals } & \multirow{2}{*}{$N$} & \multicolumn{2}{|c|}{ Length (mm) } & \multicolumn{2}{|c|}{ Diameter (mm) } \\
\hline & & & Means & $\mathrm{cV}$ & Means & $\mathrm{CV}$ \\
\hline \multirow[t]{4}{*}{ Workers } & Newly-emerged & 10 & 0.83 & $0.002 a$ & 0.17 & $0.001 \mathrm{a}$ \\
\hline & Nurse & 10 & 0.83 & $0.001 a$ & 0.14 & $0.002 b+-$ \\
\hline & Forager & 10 & 0.99 & $0.006 \mathrm{~b}$ & 0.13 & $0.001 \mathrm{~b}-$ \\
\hline & Egg-laying & 10 & 1.06 & $0.006 \mathrm{~b}$ & 0.15 & $0.001 b+$ \\
\hline \multirow[t]{2}{*}{ Queens } & Newly-emerged & 10 & 2.45 & $0.007 \mathrm{c}$ & 0.27 & $0.001 c$ \\
\hline & Egg-layer & 10 & 2.77 & $0.004 d$ & 0.27 & $0.001 \mathrm{c}$ \\
\hline
\end{tabular}

Measuremants followed by the same letter and signal do not differ by the Tukey-test (P 0.05$)$.

\section{CONCLUSION}

On the morphometric view-point the gland involvement in reproduction is clearly showed by the largest size in the egg-laying queen and worker. The reasons for the size differences of the gland in non laying workers is still unknown. The greater size of the gland in forager workers suggest that it must have some function. As happens with the Dufour gland in some species of bees (HEFETz 1987; HEFETZ et al. 1993), the forager's gland may participate in pheromone production for nest-mate or nest-entrance recognition. According ABDALLA \& CRUZ-LANDIM (2001), the Dufour gland of forager workers may participate in alarm pheromone production.

ACKNOWLEDGEMENTS. to FAPESP (Fundação de Amparo à Pesquisa do Estado de São Paulo, proc. $n^{\circ}$ 97/12243-8) by the financial and scientific support. We are also grateful for the reliable suggestions given by Dr. Edy de Lello Montenegro (UNESP, Botucatu, Brazil), Dr. José Chaud Netto (UNESP, Rio Claro) and Dr. Hayo H.W. Velthuis (Utrecht University, The Netherlands).

\section{REFERENCES}

Abdalla, F.C. \& C. Cruz-Landim. 1996. Secretory cycle of the Dufour gland in the female castes of Apis mellifera L. (Hymenoptera: Apidae). Brazil. Jour. Morphol. Sci. 13 (1): 119.

- 1997. Characterization of Dufour gland secretion and its possible origin in workers of Apis mellifera L. (Hymenoptera: Apidae) with different functions. Acta Microscopica 6 (b): 588-589.

- 2001. Behavioral responses evoked in honey bee workers by Dufour gland extracts (Hymenoptera, Apidae). Sociobiology 37 (3B): 673-678.

Abdalla, F.C.; H.H.W. Velthuis; C. Cruz-Landim \& M.J. Duchateau. 1999a. Changes in the morphology and ultrastructure of the Dufour's gland during the life cycle of the bumble bee queen,

Revta bras. Zool. 18 (Supl. 1): 119 - 123, 2001 
Bombus terrestris L. (Hymenoptera: Bombini). Neth. Jour. Zool. 49 (4): 251-261.

Abdalla, F.C.; H.H.W. Vei.thuis; M.J. Duchateau \& C. Cruz-Landim. 1999b. Secretory cycle of the Dufour's gland in workers of the bumble bee Bombus terrestris L. (Hymenoptera:Bombini). Neth. Jour. Zool. 49 (3): 139-156.

BILLEN, J.P.J. 1986. Comparative morphology and ultrastructure of the Dufour's gland in ants (Hymenoptera: Formicidae). Entomol. Gener. 11 (3/4): 165-181.

Hefetz, A. 1987. The role of Dufour's gland secretions in bees. Physiol. Entomol. 12: 243-253.

Hefetz, A.; J. TENGÖ; G. LÜBKE \& W. FranCKE. 1993. Inter-colonial and intra-colonial variation in Dufour's gland secretion in the bumble bee species Bombus hypnorum (Hymenoptera: Apidae), p. 469-480. In: K. Wiese; F.G. Gribakin \& G. REnNinger (Eds). Advances in life sciences. Sensory system of Arthropods. Basel, Birkhäuse Verlag, Vol. 11, 682p.

Katzav-Gozansky, T.; V. Soroker; A. Hefetz; M. Cojocaru; D.H. Erdmann \& W. Francke. 1997. Plasticity of caste-specific Dufour's gland secretion in the honey bee (Apis mellifera L.). Naturwissenschaften 84: 238-241.

KerR, E.W. \& E. LeLlo. 1962. Sting glands in stingless bees. A vestigial character (Hymenoptera: Apidae). Jour. N. Y. Entomol. Soc. 70: 190-214.

LELLO, E. 1971a. Adnexal gland of the sting apparatus of bees: anatomy and histology, I (Hymenoptera: Colletidae and Andrenidae). Jour. Kansas Entomol. Soc. 44: 5-13.

- 1971b. Adnexal gland of the sting apparatus of bees: anatomy and histology, II (Hymenoptera: Halictidae). Jour. Kansas Entomol. Soc. 44: 14-20.

.1971c. Adnexal gland of the sting apparatus of bees: anatomy and histology, III (Hymenoptera: Megachilidae and Melitidae). Ciência Cultura 23: 243-258.

. 197Id. Glândulas anexas ao aparelho de ferrão das abelhas, anatomia e histologia (Hymenoptera: Anthophoridae). Ciência Cultura 23 (6): 765-772. 